\title{
Does Education Affect the Online Impulse Buying in Millennials?
}

\author{
Ambica Prakash Mani, Vinayendra Mani Tripathi
}

\begin{abstract}
The popularity and acceptance of online medium for buying and selling has increased both in terms of popular acceptance and widespread reach in every nook and corner of the country. A similar rise has been observed in the tendency of online impulsive buying behaviour too. Impulsive or impulse buying is unplanned and often done in a fraction of second over some human stimulus that is usually uncontrollable. There is no doubt to the fact that the exposure and inclination towards online medium as a buying platform has increased significantly over the last few years amongst all and its rise is particularly noteworthy in the generation $Y$. Today this young and well educated group qualifies to be an important segment for marketers. This research paper explores the impact of education over online impulsive buying behaviour in millennials of today.
\end{abstract}

Keywords: Impulsive buying, online, millennials, SPSS, ANOVA

\section{INTRODUCTION}

Today we witness a lot of buying and selling due to impulsivity. It is a pervasive phenomenon, found in every society. Many times impulsive buying is equated to emotional buying. Goldenson (1984) characterized it as a complex phenomenon having a multitude of dimensions. Impulse buying is a strong, irresistible urge or a sudden and strong inclination to act without deliberation. Impulsive buying is characterized by a temptation to purchase that intensifies to such an extent that the person buys things without giving careful thought to the aftermaths or consequences that his or her purchase can lead to. Impulsive buying behavior is unplanned and unintended buying behavior. Previous research studies indicate that more than half of the purchase made in brick and mortar stores is made on impulse. Millennials also referred as generation $\mathrm{Y}$ is a cohort of consumers born between middle of 1980 to early 2000.These are young, ambitious people who are independent and modern in outlook. Generation Y is internet savvy and adventurous. Generation $\mathrm{Y}$ are the demographic cohort that follows Generation $X$ and precedes the Generation Z.

\section{LITERATURE REVIEW}

Lu (2005) linked impulsive buying tendencies with the presence of peers. The presence of peer influence increases impulsive buying.
Park, Kim and Forney (2006) found that hedonic consumption affects impulsive buying. Hedonic factors are aspects related to feeling of fun, fantasies and emotions. These factors have an indirect effect on fashion oriented impulse buying. Sneath et al. (2009) associated impulsivity on mental state; according to him depressed people buy more on impulse. Sharma et. al. (2010) asserted that variety seeking behaviour acts as fuel in increasing the impulsive buying tendencies. Bellman et. al. (1999) and Andrade (2000) reported online purchasing to be strongly associated with factors of personal characteristics, vendor or service product characteristics, website quality, and attitude towards online shopping as well as intention of buying online and decision making. Weinberg and Gottwald 1982) concluded that some human feelings have strong association with impulsive buying tendencies. These are feelings of love, hate, fear, joy, boredom, anxiety, pride, anger, sadness, greed, guilt, shame and awe (a strong feeling associated with fear or respect or wonder) which are relevant to change the consumption levels.

\section{RESEARCH METHODOLOGY}

This paper describes the online impulsive buying and explores the impact of education over such behaviour. Secondary data formed the background of the study and helped in the development of questionnaire. The data was collected from 154 respondents active over online platform falling under the age group of 18 to 35 years. This age group is popularly known as generation $\mathrm{Y}$ or millennials. Statistical Package for the Social Sciences (SPSS) is used to analyze the data. Factor analysis and Analysis of Variance (ANOVA) is used to study the impact of their education on online impulse buying.

\section{DATA ANALYSIS}

Most of the millennials surveyed are found to be unmarried and form 84 percent of the total respondents. The following table shows the educational profile of the surveyed respondents. 52.6 percent are intermediate, 30.5 percent are graduates, 6.5 percent are qualified up to matriculation and 7.8 percent have a professional degree. See Table 1 below.

Table 1: Educational Qualification

\begin{tabular}{|c|c|c|c|c|}
\hline $\begin{array}{l}\text { Educational } \\
\text { Qualification }\end{array}$ & $\begin{array}{c}\text { Frequenc } \\
\mathrm{y}\end{array}$ & $\begin{array}{c}\text { Perc } \\
\text { ent }\end{array}$ & $\begin{array}{c}\text { Valid } \\
\text { Percent }\end{array}$ & $\begin{array}{c}\text { Cumulati } \\
\text { ve } \\
\text { Percent }\end{array}$ \\
\hline $\begin{array}{cc}\text { Vali } & \text { Up to } \\
\text { d } & \text { Matric }\end{array}$ & 10 & 6.5 & 6.5 & 6.5 \\
\hline
\end{tabular}

Revised Manuscript Received on September 25, 2019.

Dr. Ambica Prakash Mani, Associate Professor, Graphic Era Deemed to be University, Dehradun, India. E-mail: drambica.comm@geu.ac.in

Dr. Vinayendra Mani Tripathi, Professor, Graphic Era Hill University, Dehradun, India. E-mail: vmtripathi@gehu.ac.in 


\begin{tabular}{|c|c|c|c|c|}
\hline $\begin{array}{c}\text { Intermediate } \\
\text { Graduate } \\
\text { Post }\end{array}$ & 41 & 52.6 & 52.6 & 59.1 \\
$\begin{array}{c}\text { graduate and } \\
\text { other }\end{array}$ & 4 & 2.6 & 2.6 & 92.2 \\
$\begin{array}{c}\text { Professional } \\
\text { degree }\end{array}$ & 12 & 7.8 & 7.8 & 100.0 \\
Total & 154 & $\begin{array}{c}100.5 \\
0\end{array}$ & 100.0 & \\
\hline
\end{tabular}

Kaiser-Meyer-Olkin (KMO) value generated is 0.753 and reflects the sampling adequacy for conducting further sophisticated analysis. As the KMO value is greater than 0.6 , the data is fit to conduct factor analysis. The following table shows all the different variables and their extraction values. The appropriateness of the sample size increases as communalities become lower. The variable, "convenience of shopping has significant influence on my online impulsive purchase" has scored highest value of 0.806 , followed by online review have significant influence on my online impulse buying" has a mean value of 0.754 .

Table 2: Communalities

\begin{tabular}{|c|c|c|}
\hline Variables & Initial & Extraction \\
\hline Convenience of shopping has significant influence on my impulsive online purchases & 1.000 & .806 \\
Price has significant influence on my impulsive online purchases & 1.000 & .744 \\
Perceived quality has significant influence on my impulsive online purchases & 1.000 & .695 \\
Discounts have significant influence on my online impulsive buying & 1.000 & .600 \\
Online reviews have significant influence on my online impulsive buying & 1.000 & .754 \\
Navigability of the website has significant influence on online impulsive buying & 1.000 & .608 \\
Free return policy has significant influence on my online impulsive buying & 1.000 & .674 \\
Gifts have significant influence on my online impulsive buying & 1.000 & .598 \\
Promotions like news paper advertisements have significant influence on my online impulsive buying & 1.000 & .699 \\
Wide variety/ options have significant influence on my online impulsive buying & 1.000 & .641 \\
Website's visual appeal has significant influence on my online impulsive buying behaviour & 1.000 & .538 \\
Availability of information online has positive influence on my online impulsive buying behaviour & 1.000 & .632 \\
Friends opinion has significant influence on my online impulsive buying behaviour & 1.000 & .693 \\
Novelty/uniqueness has significant influence on my online impulsive buying behaviour & 1.000 & .630 \\
Availability of new/ latest variant act as positive reinforce for impulsive buying & 1.000 & .600 \\
I like the excitement of online impulsive buying & 1.000 & .590 \\
online impulsive buying is fun filled & 1.000 & .697 \\
I am often surprised by my online impulsive buying & 1.000 & .723 \\
I feel relived in my stress level after indulging in on line impulsive buying & 1.000 & .635 \\
Online impulsive buying gives me social acceptance & 1.000 & .561 \\
Online impulsive buying gives me a sense of adventure impulse buying of skin care products & 1.000 & .697 \\
\hline I often feel I have spent more and unnecessarily after online impulsive buying & 1.000 & .648 \\
\hline
\end{tabular}

Extraction method: Principal component analysis

"Factor analysis" has been used to uncover the latent structure or dimensions of a set of variable. Factor Analysis is widely used to reduce space by reducing the number of factors. We have extracted seven factors namely - price variety, hedonic factors, adventure, social reasons, merchandising, online navigability and novelty and extracted the mean values. The highest mean value of 4.2917 is observed for price -variety across professional degree holders in Table 3 below.

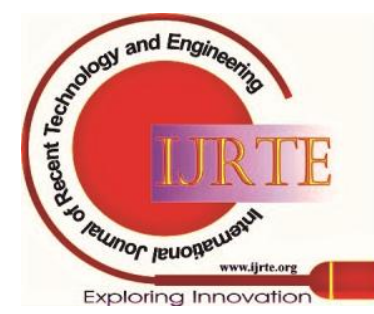


Table 3: Mean Value

\begin{tabular}{|l|c|c|c|c|c|c|c|}
\hline \multicolumn{1}{|c|}{} & & & & & & & \\
$\begin{array}{c}\text { Educational } \\
\text { Qualification/ } \\
\text { Factors }\end{array}$ & $\begin{array}{c}\text { Price } \\
\text { variety }\end{array}$ & $\begin{array}{c}\text { Hedonic } \\
\text { Factor }\end{array}$ & $\begin{array}{c}\text { Adven } \\
\text { ture }\end{array}$ & $\begin{array}{c}\text { Social } \\
\text { Factor }\end{array}$ & $\begin{array}{c}\text { Ondine } \\
\text { sing } \\
\text { Factor } \\
\text { Navigatibi } \\
\text { lity } \\
\text { and reviews }\end{array}$ & $\begin{array}{c}\text { Novelty and } \\
\text { social } \\
\text { acceptance }\end{array}$ \\
\hline Up to Matric & 3.4333 & 2.5250 & 3.2333 & 3.3000 & 3.3250 & 2.7000 & 3.0500 \\
\hline Intermediate & 3.8107 & 3.3272 & 3.3745 & 3.4691 & 3.1080 & 3.0123 & 3.1975 \\
\hline Graduate & 3.9610 & 3.3298 & 3.2482 & 3.3404 & 3.3830 & 3.0213 & 3.0957 \\
\hline $\begin{array}{l}\text { Post graduate and } \\
\text { other }\end{array}$ & 4.0833 & 3.6250 & 4.0000 & 3.5000 & 3.8125 & 3.8750 & 3.6250 \\
\hline Professional degree & 4.2917 & 3.6458 & 3.6667 & 3.8125 & 3.6875 & 3.2500 & 3.6250 \\
\hline Total & 3.8766 & 3.3084 & 3.3658 & 3.4464 & 3.2695 & 3.0357 & 3.2013 \\
\hline
\end{tabular}

Further, ANOVA is applied between the factors across educational qualifications. ANOVA is collection of statistical model used to analyze the different or variances in the group under study. One way ANOVA is applied as there is one independent variable.

Table 5 : ANOVA

\begin{tabular}{|c|c|c|c|c|c|c|c|}
\hline \multicolumn{3}{|c|}{ Factors/Education } & $\begin{array}{c}\text { Sum of } \\
\text { Squares }\end{array}$ & df & $\begin{array}{l}\text { Mean } \\
\text { Square }\end{array}$ & $\mathrm{F}$ & Sig. \\
\hline \multirow{3}{*}{$\begin{array}{l}\text { Price Variety } \\
\text { Qualification }\end{array}$} & Between Groups & (Combined) & 4.890 & 4 & 1.222 & 3.584 & .008 \\
\hline & Within Groups & & 50.822 & 149 & .341 & & \\
\hline & Total & & 55.711 & 153 & & & \\
\hline \multirow{3}{*}{$\begin{array}{l}\text { Hedonic Factor } * \text { Educational } \\
\text { Qualification }\end{array}$} & Between Groups & (Combined) & 7.954 & 4 & 1.989 & 5.151 & .001 \\
\hline & Within Groups & & 57.520 & 149 & .386 & & \\
\hline & Total & & 65.474 & 153 & & & \\
\hline \multirow{3}{*}{$\begin{array}{l}\text { Adventure } \\
\text { Qualification }\end{array}$} & Between Groups & (Combined) & 3.526 & 4 & .882 & 2.454 & .048 \\
\hline & Within Groups & & 53.534 & 149 & .359 & & \\
\hline & Total & & 57.060 & 153 & & & \\
\hline \multirow{3}{*}{$\begin{array}{l}\text { Social Factor } \\
\text { Qualification }\end{array}$} & Between Groups & (Combined) & 2.404 & 4 & .601 & 1.679 & .158 \\
\hline & Within Groups & & 53.342 & 149 & .358 & & \\
\hline & Total & & 55.746 & 153 & & & \\
\hline \multirow{3}{*}{$\begin{array}{l}\text { Merchandising Factor } * \text { Educational } \\
\text { Qualification }\end{array}$} & Between Groups & (Combined) & 6.024 & 4 & 1.506 & 5.168 & .001 \\
\hline & Within Groups & & 43.417 & 149 & .291 & & \\
\hline & Total & & 49.442 & 153 & & & \\
\hline \multirow{3}{*}{$\begin{array}{l}\text { Online navigability and reviews * } \\
\text { Educational Qualification }\end{array}$} & Between Groups & (Combined) & 4.550 & 4 & 1.137 & 2.438 & .050 \\
\hline & Within Groups & & 69.504 & 149 & .466 & & \\
\hline & Total & & 74.054 & 153 & & & \\
\hline \multirow{3}{*}{$\begin{array}{l}\text { Novelty and social acceptance * } \\
\text { Educational Qualification }\end{array}$} & Between Groups & (Combined) & 3.626 & 4 & .907 & 1.997 & .098 \\
\hline & Within Groups & & 67.634 & 149 & .454 & & \\
\hline & Total & & 71.260 & 153 & & & \\
\hline
\end{tabular}

As observed in the ANOVA Table 5 above the significant value for merchandising and hedonic a factor both are 0.001 and are less than 0.005 .

This confirms that there is significant differential impact of educational qualification for merchandising and hedonic factors. Hence "educational qualification" impacts online impulsive buying for these two factors for the millennials.

\section{CONCLUSIONS}

Convenience of shopping, online navigability and availability of reviews are considered to be most important factors in online impulsive buying of millennials. PriceVariety emerges as the most important factor impulse buying provocation for generation $\mathrm{Y}$ consumers. This also proves that the millennials take their wise decisions when it comes to spending money based on price variety determinant. Based on educational qualification generation $\mathrm{Y}$ respondents have different opinions towards merchandising and hedonic factors and this influences their online impulse purchase decisions. Education of the respondents affects the merchandising as the way products are displayed over the online medium will be perceived differently by millennials. Similarly hedonic factors that are related to the fun associated with impulse purchases will be perceived differently by the generation $\mathrm{Y}$ people based on their educational qualifications.

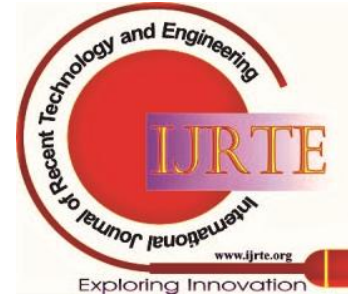




\section{LIMITATIONS AND SCOPE OF FUTURE \\ RESEARCH}

This research is carried out for impulse buying over online platform with a limited sample comprising of generation Y falling in the age group of 18 to 35 years. Similar research can be carried with a larger sample across different age groups. Education is the only dimension considered; future research may be carried with different variables.

\section{REFERENCES}

1. Luo, X. (2005). How Does shopping with Others Influence Impulsive Purchasing. Journal of Consumer Psychology. 15(4), 288-294.

2. Park,E. J., Kim. E.Y., Forney, J. C. (2006). A Structural Model of Fashion Oriented Impulse Buying Behaviour. Journal of Fashion Marketing and Management. 10(4), 433-446.

3. Sneath, J. Z., Lacey, R., Kennett-Hensel., P.A. (2009). Coping with Natural Disaster: Losses, Emotions and Impulsive and Compulsive Buying, Marketing Letters. 20 (1). 45-60.

4. Sharma, P., Sivakumaran, B., Marshal, R. (2010). Impulse Buying and Variety Seeking: A Trait correlates Perspective. Journal of Product \& Brand Management. 17 (1), 25-36.

5. Weinber, Peter, Gottwald, Wolfgang (1982) .Impulsive consumer buying as a result of emotions. Journal of Business Research. 10 (1) 43-57.

6. Andrade, E. (2000). Identifying discriminating variables of online and offline buyers: A perceived-risk approach, Proceedings of the 6th Americas Conference on Information Systems, pp. 1386-1392

7. Bellman, S., Lohse, G., and Johnson, E. (1999). Predictors of online buying behavior, Communications of the ACM (42:12), pp. 32-38. 